УДК 625.078.1

\title{
ПРОПОЗИЦЇ̈ ЩОДО ВДОСКОНАЛЕННЯ ТЕХНОЛОГІЇ ОБРОБКИ КОНТЕЙНЕРОПОТОКІВ У МЕЖАХ МІЖНАРОДНИХ ТРАНСПОРТНИХ КОРИДОРІВ
}

Д-р техн. наук Є.С. Альошинський, магістр О.В. Бондаренко

\section{ПРЕДЛОЖЕНИЯ ПО СОВЕРШЕНСТВОВАНИЮ ТЕХНОЛОГИИ ОБРАБОТКИ КОНТЕЙНЕРОПОТОКОВ В РАМКАХ МЕЖДУНАРОДНЫХ ТРАНСПОРТНЫХ КОРИДОРОВ}

Д-р техн. наук Е.С. Алёшинский, магистр А.В. Бондаренко

\section{SUGGESTIONS TO IMPROVE PROCESSING TECHNOLOGY OF CONTAINER WITHIN INTERNATIONAL TRANSPORT CORRIDORS}

Doct. of techn. sciences E. Alyoshinsky, master A. Bondarenko

Проведено аналіз сучасного стану проблем розвитку контейнерних перевезень та аналіз системи організації й обробки контейнерів митною службою України. Розроблено раціоналізовану систему пропуску контейнеропотоків у межах міжнародних транспортних коридорів (МТК).

Запропоновано підходи щзодо вдосконалення системи пропуску вантажопотоків у межах МТК та впровадження новітніх систем контролю схоронності вантажів при пропуску контейнеропотоків по МТК. Сформовано процедуру деконцентрації митних операцій з припортової зони до внутрішньодержавних термінальних потужностей.

Ключові слова: вантажні перевезення, деконщентрація середовища, митні операції, моделювання, міжнародні транспортні коридори.

Проведен анализ современного состояния проблем развития контейнерных перевозок, анализ системы организации и обработки контейнеров таможенной службой Украины. Разработана рационализированная система пропуска контейнеропотоков в рамках международньх транспортных коридоров (МTK).

Предложены подходы к совершенствованию системы пропуска грузопотоков в пределах МТК и внедрение новейших систем контроля сохранности грузов при пропуске контейнеропотоков по МTK. Сформирована процчедура деконцеентрации таможенных операций с припортовой зоны к внутригосударственным терминальным мошиостям.

Ключевые слова: грузовые перевозки, деконцентрация среды, таможенные операции, моделирование, международные транспортные коридоры. 
The analysis of the current state of development of container transport problems, the analysis of the organization and handling of containers Customs Service of Ukraine. Designed to streamline the system of container passes through international transport corridors (ITC).

Approaches to improve the passing of traffic within the MTC and the introduction of new systems of control of safety of cargoes at the admission of container for MTC. Formed procedure deconcentration of customs operations of the port zone to the domestic terminal facilities.

Keywords: freight transportation, deconcentration environment, customs operations, modeling, international transport corridors.

Вступ. На сьогоднішній день розвиток вантажних перевезень знаходиться у перехідному стані. Зношена інфраструктура, дефіцит рухомого складу, обмеженість ресурсів - все це спонукає до розвитку контейнерних перевезень (рис. 1).

Даний вид транспортування застосовується для доставки широкої номенклатури вантажів у країнах Європи та Азії, але в Україні в період з 2009 року спостерігається відносно низький рівень росту контейнеризації. За умови наявності великої кількості терміналів 3 обробки контейнерів їхня завантаженість складає близько $65 \%$, що $\epsilon$ недоцільним в умовах конкуренції на ринку вантажних перевезень. Близько $70 \%$ контейнерів по території України транспортуються приватним автомобільним транспортом, хоча він не $\epsilon$ найбільш раціональним варіантом для перевезень на великі відстані. Всі ці аспекти обумовлюють необхідність завантаження наявних контейнерних терміналів 3 метою розвитку транспортного сектора економіки [2].

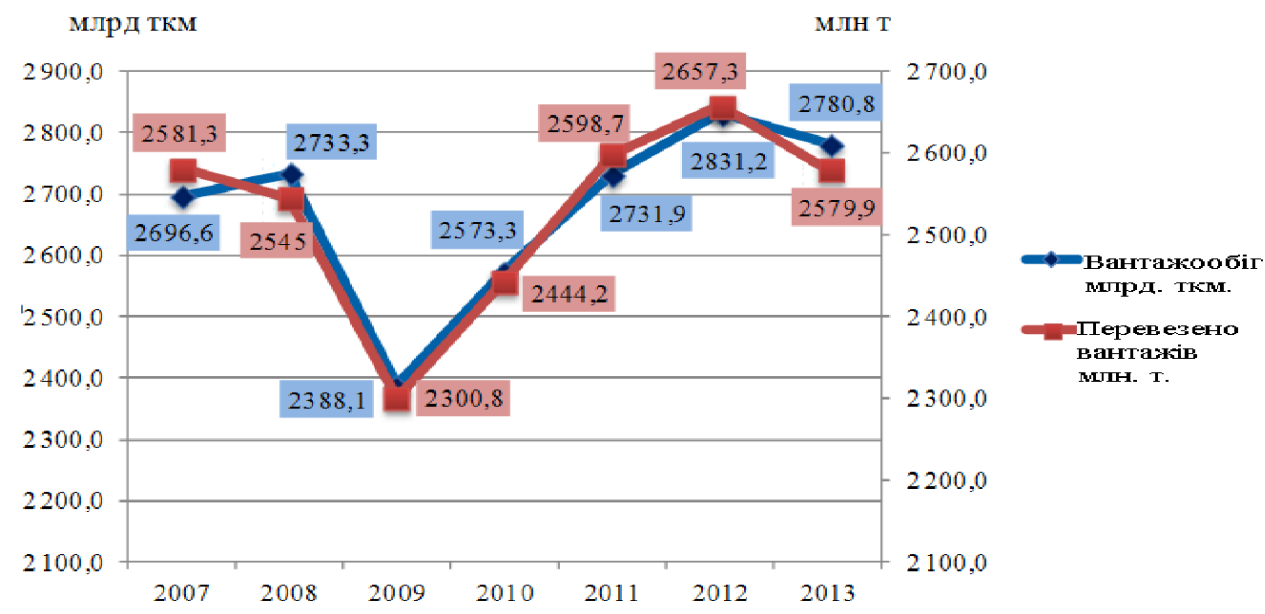

Рис. 1. Динаміка обсягів перевезень вантажів і вантажообігу на залізничній мережі країн СНД

Основна частина. Функціонування системи пропуску контейнеропотоків у межах міжнародних транспортних коридорів (на прикладі морського та залізничного транспорту) ілюструється таким чином: при виникненні взаємодії між зовнішнім i внутрішнім полігонами утворюється ланцюг перевізників, який задовольняе потреби у перевезенні окремої контейнерної відправки. Насамперед, врахувавши специфіку географічного положення України, розглянемо більш детально процес накопичення простоїв контейнером, якщо він транспортується повз територію нашої країни.
На рис. 2 зображена схема формування початкових затримок, які у свою чергу виникають при наявних властивостях досліджуваного середовища.

Якщо подати територію нашої країни у вигляді просторового середовища, яке має перелік певних властивостей (кордони, розміри, зв'язки (інфраструктуру) та ін.), доцільно ввести такі поняття :

- концентроване середовище - сукупність об'єктивних умов простору, які не дозволяють зовнішнім елементам потрапляти до середовища; 


\section{Експлуатація залізниць}

- неконцентроване середовище сукупність об'єктивних умов простору, які спонукають зовнішні елементи до входження в середовище.

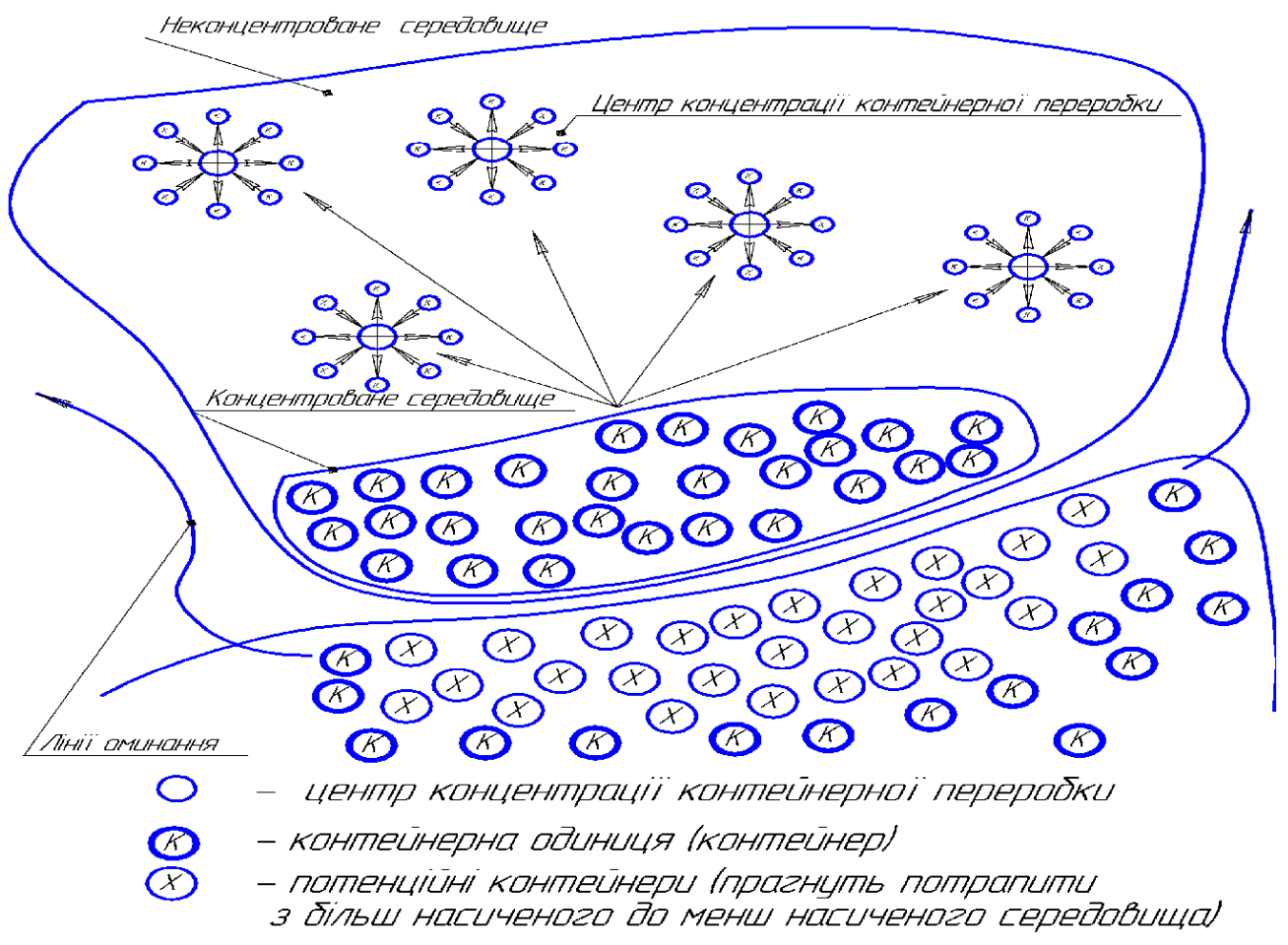

Рис. 2. Формування затримок контейнерів

Використовуючи ці поняття, розглянемо більш докладно природу виникнення затримок на прикладі контейнеропотоків.

За умови визнання контейнерного середовища гомогенним поведінка потоків ілюструється наступним чином. Концентроване середовище формується i підтримується завдяки постійним «вливанням» контейнерів (заходження контейнеровозів до портів, прибуття контейнерних поїздів тощо) i функціонує 3 максимальною продуктивністю до моменту його перевантаження.

Перенасичення настає тоді, коли наявні потужності середовища не здатні переробити матеріальні та інформаційні потоки, в результаті цього запускається механізм збільшення затримок, який продовжує накопичувати час на кожному 3 подальших етапів обробки контейнера. Формується так звана «черга» 3 тих контейнерів, які знаходяться в концентрованому середовищі, і з тих, що намагаються до нього потрапити. Нові «вливання» стають неможливими i відбувається переорієнтація контейнерів, що знаходяться в «черзі» на інші менш концентровані середовища, тобто імпортні контейнеропотоки огинають кордони нашої держави i прагнуть до якнайшвидшої доставки до пункту призначення через території інших країн.

Для виявлення найбільш вузьких місць «середовища накопичення» проведено аналіз всіх можливих причин затримки контейнерів у портах України. Найбільш вагомими (серед більше 40 виявлених) причинами $є$ :

- митний огляд;

- митне оформлення контейнера;

- технічна або комерційна несправність контейнера;

- невідповідність або відсутність генеральної декларації;

- затримка фітосанітарною, ветеринарною чи карантинною службами;

- затримка службами екологічного та радіаційного контролю;

- неправильність

оформлення

супровідних документів;

- відсутність інформації в центральній базі даних митниці; 
- відсутність рахунку-фактури;

- інші причини.

Велика концентрація затримок на кордоні України сприяє виникненню дестабілізуючого ефекту системи обробки контейнерів.

Пропонується розосередити концентроване середовище на більш оптимальні розмірні одиниці в просторі. Мається на увазі перерозподіл операцій 3 обробки елементів системи між існуючими потужностями для досягнення максимального ефекту і залучення нових контейнеропотоків через збалансовану (розвантажену) систему.

Проведені дослідження довели, що одним iз найперспективніших напрямків оптимізації мультимодальних перевезень для України може стати перенесення ряду операцій, пов'язаних 3 обробкою імпортних контейнерів, до регіональних терміналів, що дозволить розвантажити прикордонні потужності для ефективної обробки транзитних потоків. Це надасть можливість сконцентрувати свою увагу на більш однорідних технологічних процесах.

Для підвищення схоронності вантажів у процесі транспортування територією України раціональним $\epsilon$ залучення інноваційних технологій, які позитивно зарекомендували себе як концептуально новий спосіб контролю за місцезнаходженням вантажу, транспортного засобу та несанкціонованого доступу до контейнера. Використання електронних запірно-пломбуючих пристроїв (ЗПП) дає змогу контролювати доступ до вантажу в процесі його транспортування, виключити крадіжки та заміну вантажу до прибуття його до внутрішньодержавного пункту митного контролю, що в умовах сучасного ринку транспортних послуг є вагомим критерієм для вибору варіанта доставки вантажу вантажовідправником.

Математична постановка задачі. Формування чіткої розподіленості «навантаження» на кожен елемент системи обробки вхідних контейнеропотоків обумовлює розгляд двох середовищ:

- прикордонного;

- внутрішньодержавного.

До прикордонного слід віднести основні потужності з переробки контейнеропотоку, які сконцентровані на ст. Іллічівськ-Порт $(1,15$ млн TEU на рік) та ст. Одеса-Порт (900 тис TEU на рік).
Внутрішньодержавні потужності формуються за рахунок терміналів, існуючих на базі філій УДЦТС «Ліски», а саме: м. Чоп (300 TEU за добу), м. Київ (500 TEU за добу), м. Одеса (600 TEU за добу), м. Харків (500 TEU за добу), м. Дніпропетровськ (500 TEU за добу).

В умовах незбалансованої завантаженості потужностей стає неможливим подальше утримання устаткування, персоналу тощо.

Для обробки заданих об'ємів контейнеропотоків, які планується переорієнтувати для подальшої обробки 3 прикордонного середовища, до внутрішньодержавного виділені такі людські ресурси та служби:

- працівники митниці - 20 люд;

- співробітники фітосанітарного, ветеринарного, санітарно-карантинного контролю, екологічного та радіаційного контролю - 14 люд;

- співробітники терміналів, причетні до контрольних процедур перевірки - 30 люд.

3 працівників наведених вище служб сформовані два типи контролюючих бригад 3 відповідними переробними спроможностями, перший тип - 40 конт./доб; другий тип 32 конт./доб [4].

Перший тип :

- працівникі митниці - 5 люд;

- співробітники фітосанітарного, ветеринарного, санітарно-карантинного контролю, екологічного та радіаційного контролю - 3 люд;

- співробітники терміналів, причетні до процедур перевірки - 7 люд.

Другий тип :

- працівникі митниці - 3 люд;

- співробітники фітосанітарного, ветеринарного, санітарно-карантинного контролю, екологічного та радіаційного контролю - 2 люд;

- співробітники терміналів, причетні до процедур перевірки - 4 люд.

Розрахуємо необхідну кількість контролюючих бригад першого та другого типів для виконання заданих об'ємів робіт в найкоротший термін.

Нехай $x_{1}$ - необхідна кількість терміналів 1-го типу, а $x_{2}$ - 2-го типу, тоді цільова функція буде мати вигляд

$$
f(k)=40 x_{1}+32 x_{2} \rightarrow \max .
$$

Обмеження набувають вигляду 


$$
\left\{\begin{array}{l}
5 x_{1}+3 x_{2}<20 \\
3 x_{1}+2 x_{2} \leq 14 \\
x_{1}+x_{2} \leq 32 \\
x_{1}, x_{2} \geq 0
\end{array}\right.
$$

Проводимо обчислення в середовищі програмного продукту Graphic LP Optimizer (рис. 3).

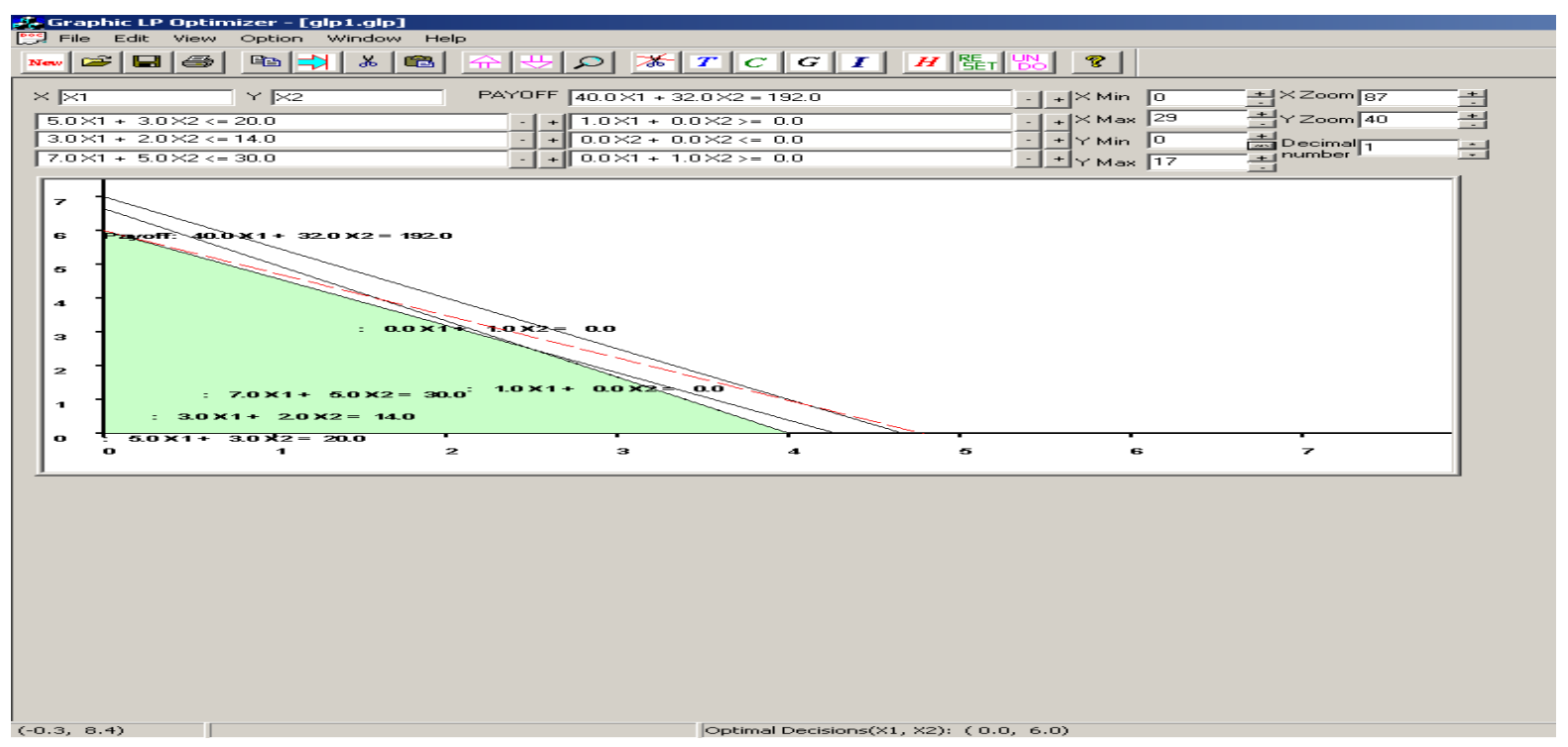

Рис. 3. Програмний інтерфейс моделі розрахунку перерозподілу потужностей

При обчисленні параметрично заданих обмежень отримуємо глобальний оптимум: $x_{1}=0 ; x_{2}=4$, тобто оптимальним $є$ залучення шести контролюючих бригад другого типу, які у свою чергу здатні перероблювати добовий потік в розмірі 192 контейнерів. Річний переорієнтований потік складе - 70080 контейнерів, за умови обмеженої кількості технологічних потужностей.

3 урахуванням проведеного моделювання для раціоналізації технологічного процесу (ТП) пропонується удосконалена структурна схема обробки імпортного контейнеропотоку в розподіленому середовищі (рис. 4).

$\mathrm{Ha}$ рис. 4 нумерованими блоками позначаються такі операції:

1- надходження інформації про наявні вантажі для отримання дозволу на судозахід (за одну добу до прибуття);

2- надходження заявки від морського агента до прикордонників (за чотири години до прибуття судна);

3- по прибутті уточнення інформації про маршрут, характер контейнерів;
4- подання товарно-транспортних документів, списку контейнерів для виконання вантажних операцій;

5- передача перевізником товарнотранспортних документів співробітникам прикордонного наряду;

6- оформлення екіпажу, транспортних засобів та ін.;

7- прикордонний огляд;

8- вантажні операції;

9- попередній огляд контейнерів (під час вантажних операцій);

10- контроль наявності пломб та цілісності контейнерів (під час вантажних операцій);

11- контрольний огляд контейнерів (після закінчення вантажних операцій);

12- відправлення транспортного засобу;

13- перевірка правильності оформлення документів, відправлення інформації в центральну базу митниці;

14- відправлення попередньої заявки на виплату накладених митних платежів;

15- вантажні операції в контейнерному терміналі (по прибутті); 
16- митний огляд;

17- огляд фітосанітарною, ветеринарною, санітарно-карантинною службами, службою екологічного та радіаційного контролю;
18- вантажні операції в контейнерному терміналі (по відправленні);

19- прибуття вантажу вантажоотримувача [3].

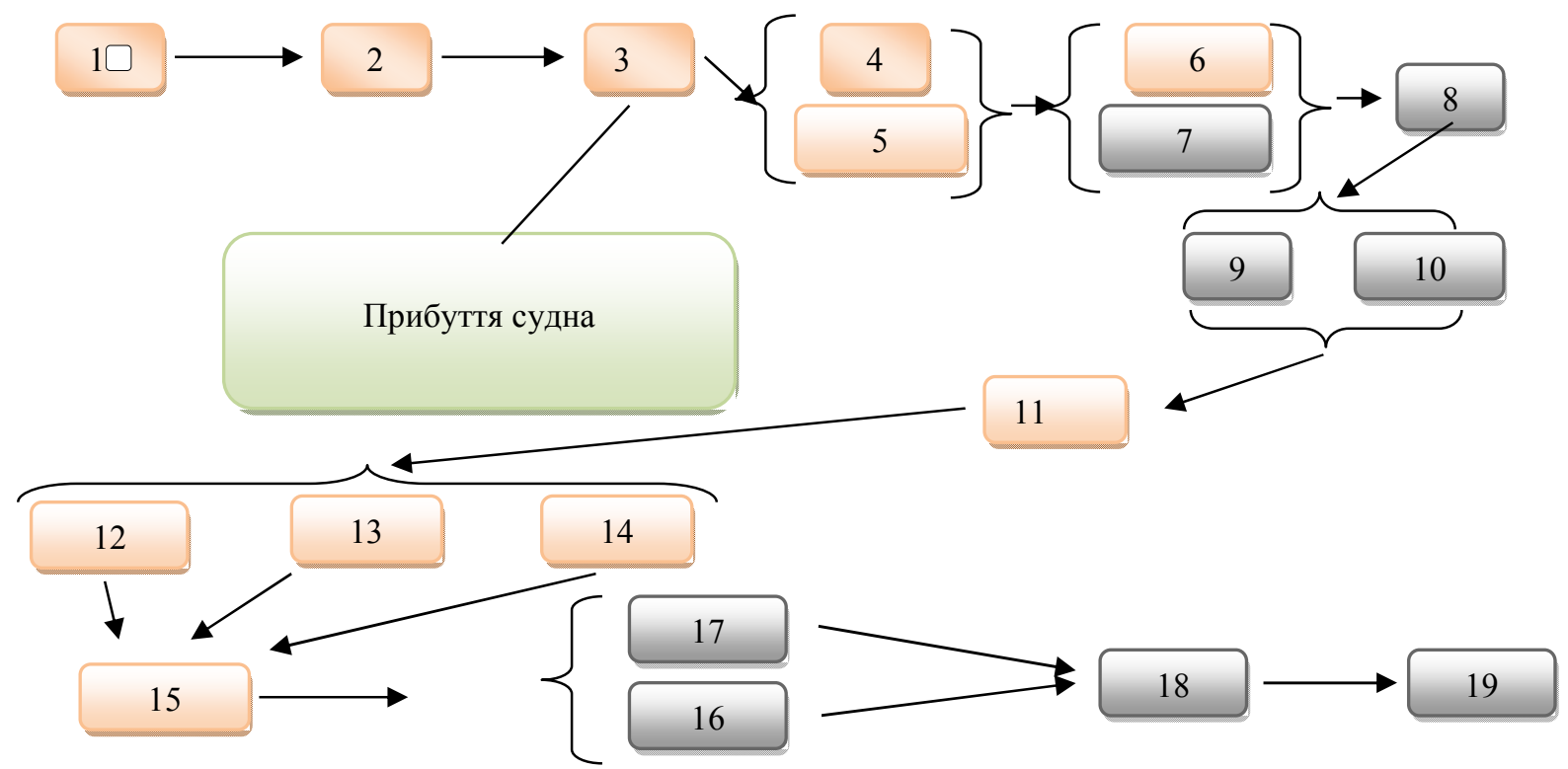

Рис. 4. Удосконалена схема обробки імпортного контейнеропотоку в розподіленому середовищі

Перенесення частини операцій з обробки імпортних контейнерів на внутрішньодержавні термінали дасть змогу збільшити частку мультимодальних перевезень, тим самим нівелювати недоліки кожного 3 видів транспорту та використовувати принципи раціонального сегментування ринку транспортних послуг на кожному з етапів транспортування.

Висновки. Проведено аналіз сучасних проблем розвитку мультимодальних контейнерних перевезень України. Визначено основні фактори впливу на імпортні контейнеропотоки, що дозволило вивести їх взаємозв'язок 3 внутрішньою транспортнотермінальною системою переробки міжнародного контейнеропотоку. Розроблено пропозиції щодо вдосконалення технології обробки мультимодальних контейнерних перевезень, на основі яких побудовано удосконалену схему обробки імпортного контейнеропотоку в розподіленому середовищі. Запропоновано комплекс заходів 3 перерозподілу завантаження існуючої ресурсно-технічної бази залізничного транспорту 3 припортових у внутрішні транспортні комплекси.

\section{Список використаних джерел}

1. Сич, Є.М. Економічні аспекти контейнерно-контрейлерного обслуговування клієнтури залізничного транспорту [Текст] / С.М. Сич, Н.І. Богомолова, М.М. Андрієнко та [ін.]. - К.: Логос, 2007. $-392 \mathrm{c}$.

2. Абрамов, А.П. Контейнерные перевозки на железнодорожном транспорте [Текст] / А.П. Абрамов. - М.: РГОТУПС, 2004. -235 с.

3. Кушнірчук, В.Г. Соціально-економічна ефективність інтермодальних перевезень [Текст] / В.Г. Кушнірчук // Проблеми економіки транспорту: матеріали IV міжнародної наук. конф. Дніпропетровськ: Вид-во Дніпропетр. нац. ун-ту залізн. трансп. ім. акад. В.Лазаряна, 2005. - С. 83-84.

4. Альошинський, Є.С. Пропозиції щодо покращення функціонування комплексів 3 обслуговування міжнародних контейнерних перевезень. Удосконалення управління експлуатаційною роботою залізниць [Текст] / С.С. Альошинський, Г.І. Шелехань // Зб. наук. праць. - Харків: УкрДАЗТ, 2007. - Вип. 85. - С. 178-182. 
5. Данько, M.I. Вибір пропозицій по удосконаленню організації митних операцій на транспорті для підвищення конкурентоспроможності системи міжнародних перевезень України [Текст] / М.I. Данько, Є.С. Альошинський, Д.А. Шварьов // Залізничний транспорт України. - 2008. - № 3. C. $18-20$.

6. Балака, Є.І. Оцінка економічної доцільності інвестицій в інноваційні проекти на транспорті [Текст] / С.І. Балака, О.І. Зоріна, Н.М. Колесникова. - Харків, 2005. - 210 с.

7. Ellis, W.E., Port Authority of New York and New Jersey Inland Satellite Ports Initiative, presented at the 80th annual meeting of the Transportation Research Board. - Washington, D.C., January 2001.

8. Альошинський, Є.С. Основи формування процесу міжнародних вантажних залізничних перевезень [Текст]: дис... д-ра техн. наук: 05.22.01 / Альошинський Євген Семенович. - Харків, 2009. $-611 \mathrm{c}$.

9. Альошинський, С.С. Можливості раціоналізації процесу виконання митних операцій на припортових залізничних станціях [Текст] / Є.С. Альошинський, С.О. Світлична, Т.Г. Стягін [та ін.] // Східно-європейський журнал передових технологій. - 2011. - № 2/3 (50). - С. 14-18.

10. Base Realignment and Closure (BRAC) accessed April 2007, see www.defense-link.mil/brac/.

11. BTS-Bureau of Transportation Statistics, America's Container Ports: Delivering the Goods, Washington, D.C April 2007. Available at www.dot.gov/-affairs/briefing.htm. $22-27$.

12. Biederman, D. and B. Dibenedetto, "Twist of Fate," Journal of Commerce, Vol. 8, Issue 14, pps

\footnotetext{
Альошинський Свген Семенович, д-р техн. наук, професор, завідувач кафедри транспортних систем та логістики Українського державного університету залізничного транспорту. Тел.: (057) 730-19-55.

Бондаренко Олександр Вікторович, магістр, кафедра транспортних систем та логістики Український державний університет залізничного транспорту.

Alyoshinsky Eugen Semenovich d-r of techn. sciences, professor, head of department of transport systems and logistics Ukrainian State University of Railway Transport. Tel.: (057) 730-19-55.

Bondarenko Alexander, MA department of transport systems and logistics Ukrainian State University of Railway Transport.
}

Стаття прийнята 2.07.2015 p. 